\title{
Corticosteroid treatment for traumatic acute subdural haematoma, maybe not such a good idea
}

\author{
Diane Demailly, ${ }^{1}$ Pierre Henri Lefevre, ${ }^{4}$ Dimitri Renard ${ }^{1}$
}

${ }^{1}$ Neurology, Nîmes University Hospital, Nîmes, France ${ }^{4}$ Radiology, Nîmes University Hospital, Nîmes, France

Correspondence to Dr Dimitri Renard, dimitrirenard@hotmail.com

Accepted 12 May 2017
CrossMark

To cite: Demailly $D$, Lefevre PH, Renard D. BMJ Case Rep Published Online First: [please include Day Month Year]. doi:10.1136/ bcr-2017-220344

\section{DESCRIPTION}

An 86-year-old woman with acute blunt head trauma (the patient's head was hit by a car) 10 days ago, associated with a right occipital fracture and an acute subdural haematoma (treated in the department of neurosurgery by oral prednisone $80 \mathrm{mg}$ once a day) (figure 1), presented with focal left arm motor seizures. At that time, CT and MRI showed right cortical venous thrombosis (figure 1), absent on initial CT imaging. Corticosteroids were stopped and antiepileptic drugs and anticoagulation (warfarin) started. Three weeks later, CT showed complete resolution of the cortical venous thrombosis and spontaneous resorption of the subdural haematoma. Blood analyses in search of a prothrombotic state were negative in the absence of other blood test abnormalities (including normal metabolic profile).

Despite the lack of evidence-based efficacy, steroids are sometimes used in the non-surgical treatment of chronic (and sometimes also acute) subdural haematoma. ${ }^{1}$ Venous sinus thrombosis is relatively frequent after blunt head trauma (described in up to $16 \%$ of patients with acute blunt trauma), especially in the presence of skull fracture (associated with a risk of $20 \%$ for venous sinus thrombosis). ${ }^{2}$ The recommended treatment by anticoagulation of these post-traumatic venous sinus thrombosis patients is unclear because of frequently associated traumatic intracranial haemorrhage. The exact underlying pathophysiological mechanism of these trauma-related venous sinus thromboses is unknown. In our patient, other risk factors for venous sinus thrombosis might have also played a role, for example, intracranial hypotension due to a traumatic dural tear (although radiological abnormalities often seen in

\section{Learning points}

- Clinically, suspecting venous sinus thrombosis after head trauma is often not evident since both disorders are classically associated with headache.

- Venous sinus thrombosis is relatively frequent after blunt head trauma.

- Corticosteroid treatment is controversial as treatment for subdural haematoma. Because of the frequently associated venous sinus thrombosis, corticosteroids have to be used with caution (or even simply avoided) in acute traumatic subdural haematoma.

intracranial hypotension lacked) or pre-existing dehydration (often present in elderly patients, although dehydration-related blood abnormalities lacked in our patient).

In conclusion, corticosteroid treatment (with its possible associated prothrombotic effect) has to be used with caution in traumatic acute subdural haematoma.

Contributors All authors participated and agreed with the full content of the manuscript. DD contributed for the analysis of the data and the writing of the paper. PHL contributed for the analysis and interpretation of the data. DR contributed for the analysis and interpretation of the data and the writing of the paper.

Competing interests None declared.

\section{Patient consent Obtained.}

Provenance and peer review Not commissioned; externally peer reviewed.

(C) BMJ Publishing Group Ltd (unless otherwise stated in the text of the article) 2017. All rights reserved. No commercial use is permitted unless otherwise expressly granted.

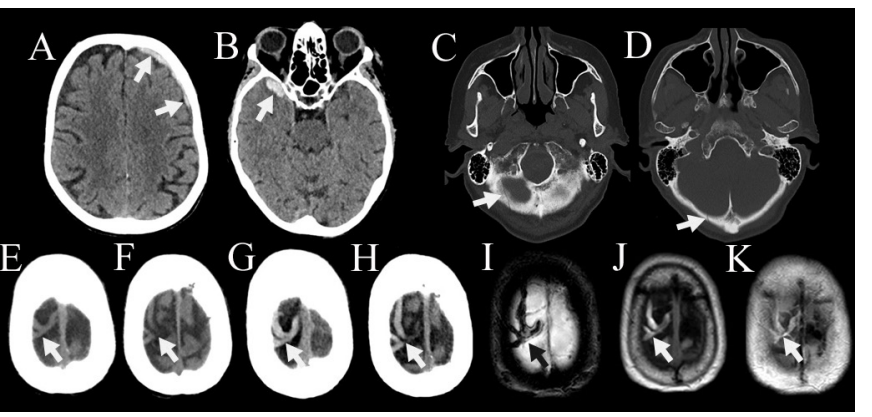

Figure 1 Initial CT showing frontal (A) and temporal (B) acute subdural haematoma and right occipital fracture ( $C$ and D), without venous signal abnormalities ( $E$ and $F$ ). Ten days later, non-enhanced CT showed cortical venous hyperdensity $(\mathrm{G}$ and $\mathrm{H})$ and MRI confirmed cortical venous thrombosis $\left(\mathrm{I}, \mathrm{T} 2^{*}\right.$; J, non-enhanced $\mathrm{T} 1$; $\mathrm{K}$, fluid attenuation inversion recovery). 
Images in...

\section{REFERENCES}

1 Berghauser Pont LM, Dirven CM, Dippel DW, et al. The role of corticosteroids in the management of chronic subdural hematoma: a systematic review. Eur I Neurol 2012;19:1397-403.
2 Delgado Almandoz JE, Kelly HR, Schaefer PW, et al. Prevalence of traumatic dural venous sinus thrombosis in high-risk acute blunt head trauma patients evaluated with multidetector CT venography. Radiology 2010;255:570-7.

Copyright 2017 BMJ Publishing Group. All rights reserved. For permission to reuse any of this content visit

http://group.bmj.com/group/rights-licensing/permissions.

BMJ Case Report Fellows may re-use this article for personal use and teaching without any further permission.

Become a Fellow of BMJ Case Reports today and you can:

- Submit as many cases as you like

- Enjoy fast sympathetic peer review and rapid publication of accepted articles

- Access all the published articles

Re-use any of the published material for personal use and teaching without further permission

For information on Institutional Fellowships contact consortiasales@bmjgroup.com

Visit casereports.bmj.com for more articles like this and to become a Fellow 